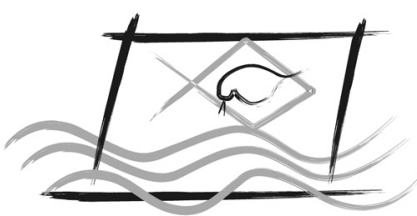

ECOTOX - BRASIL

\title{
Toxicity of Glyphosate on Physalaemus albonotatus (Steindachner, 1864) from Western Brazil
}

\author{
F. Simioni ${ }^{1}$, D.F.N. DA Silva ${ }^{2} \&$ T. MotT $^{3}$ \\ ${ }^{1}$ Laboratório de Herpetologia, Instituto de Biociências, Universidade Federal de Mato Grosso, Cuiabá, Mato Grosso, Brazil. \\ ${ }^{2}$ Programa de Pós-Graduação em Ecologia e Conservação da Biodiversidade, Universidade Federal de Mato Grosso, Cuiabá, Mato Grosso, Brazil. \\ ${ }^{3}$ Setor de Biodiversidade e Ecologia, Universidade Federal de Alagoas, Av. Lourival Melo Mota, s/n, Maceió, Alagoas, CEP 57072-970, Brazil.
}

(Received April 12, 2012; Accept April 05, 2013)

\begin{abstract}
Amphibian declines have been reported worldwide and pesticides can negatively impact this taxonomic group. Brazil is the world's largest consumer of pesticides, and Mato Grosso is the leader in pesticide consumption among Brazilian states. However, the effects of these chemicals on the biota are still poorly explored. The main goals of this study were to determine the acute toxicity $\left(\mathrm{CL}_{50}\right)$ of the herbicide glyphosate on Physalaemus albonotatus, and to assess survivorship rates when tadpoles are kept under sub-lethal concentrations. Three egg masses of P. albonotatus were collected in Cuiabá, Mato Grosso, Brazil. Tadpoles were exposed for $96 \mathrm{~h}$ to varying concentrations of glyphosate to determine the $\mathrm{CL}_{50}$ and survivorship. The $\mathrm{CL}_{50}$ was $5.38 \mathrm{mg} \mathrm{L}^{-1}$ and there were statistically significant differences in mortality rates and the number of days that $P$. albonotatus tadpoles survived when exposed in different sub-lethal concentrations of glyphosate. Different sensibilities among amphibian species may be related with their historical contact with pesticides and/or specific tolerances. Further studies are required to determine the degree to which this taxonomic group is threatened by chemical contaminants.
\end{abstract}

Key-words: Amphibia, $\mathrm{CL}_{50}$, Herbicide, Mato Grosso, survival, tadpole.

Toxicidade do glifosato em Physalaemus albonotatus (Steindachner,1864) do Oeste brasileiro

\section{Resumo}

O declínio populacional de anfíbios tem sido observado mundialmente e agrotóxicos podem impactar negativamente este grupo taxonômico. O Brasil é o maior consumidor mundial de agrotóxicos, e Mato Grosso, o estado brasileiro que lidera este consumo. Entretanto, efeitos dos agrotóxicos sobre a biota ainda foram pouco investigados. Os principais objetivos deste estudo foram determinar o efeito agudo $\left(\mathrm{CL}_{50}\right)$ do herbicida glifosato em Physalaemus albonotatus e avaliar a taxa de sobrevivência quando girinos são mantidos em concentrações sub-letais. Três desovas de $P$. albonotatus foram coletadas em Cuiabá, Mato Grosso, Brasil. Girinos foram expostos por 96 horas em concentrações variadas de glifosato para a determinação de $\mathrm{CL}_{50}$ e sobrevivência. $\mathrm{O} \mathrm{CL}_{50}$ foi $5.38 \mathrm{mg} \mathrm{L}^{-1}$ e houve diferenças significativas nas taxas de mortalidade e no número de dias que os girinos de $P$. albonotatus sobreviveram quando expostos as diferentes concentrações sub-letais de glifosato. Sensibilidades diferentes entre espécies de anfíbios aos agrotóxicos podem estar relacionadas com o contato histórico e/ou tolerâncias específicas. Outros estudos são necessários para determinar o quanto este grupo taxonômico está sendo ameaçado por estes contaminantes químicos.

Palavras-chave: Amphibia, $\mathrm{CL}_{50}$, Herbicida, Mato Grosso, sobrevivência, girino. 


\section{INTRODUCTION}

Amphibian declines have been reported and discussed worldwide (Stuart et al., 2004; Beebee \& Griffiths, 2005; Wake \& Vredenburg, 2008) with much of the recent interest focused on the role of pesticides (Houlahan et al., 2001; Davidson et al., 2001, 2002; Davidson, 2004; Hayes et al., 2006, 2010; May, 2010; Lawrence \& Isioma, 2010). Brazil has both the greatest biodiversity worldwide and is simultaneously the world's largest consumer of pesticides (Pacheco, 2009), mainly due to its industrial scale agriculture that has rapidly expanded into the Cerrado and Amazonian biomes (Schiesari \& Grillitsch, 2011). However, the impacts of agricultural pesticide runoff on Brazilian amphibians have not been well explored. This is particularly alarming given that declining amphibian populations in United States have been correlated with greater amounts of up wind agriculture, where pesticide use is common (Davidson et al., 2001, 2002).

Up to $90 \%$ of pesticides never reach their intended targets (Sparling et al., 2001) and amphibians are one of the nontarget biological groups mostly affected (Fulton \& Chambers, 1985; Berrill et al., 1994; Sparling et al., 2001). Glyphosate is a post-emergence, non-selective aminophosphonatetype herbicide and is currently the most popular single crop protection chemical product on the market (Woodburn, 2000; Júnior \& Santos, 2002), probably due to its broad-spectrum. Glyphosate is generally regarded as an environmentally friendly herbicide because of its biodegradability and strong adsorption by soil (Barja \& Santos, 2005; Vereecken, 2005). However, some studies have indicated that glyphosate can cause negative impacts on the biota (Folmar et al., 1979; Langiano \& Martinez, 2008; Romano et al., 2008), including amphibians (Releya, 2005; Releya \& Jones, 2009). Here we evaluate the toxic effects of glyphosate on Physalaemus albonotatus (Steindachner, 1864), a widely distributed anuran in Brazil (Mato Grosso and Mato Grosso do Sul States), Argentina, Bolivia and Paraguay (Frost, 2011).

\section{MATERIAL AND METHODS}

Three egg masses of Physalaemus albonotatus were collected in Cuiabá municipality, Mato Grosso State, Brazil in March 2011. Egg masses of Physalaemus genus (Leiuperidae) are easily visible, forming a foam nest floating on the water surface (Haddad \& Prado, 2005). Each egg mass was at least $1 \mathrm{~km}$ away from the nearest other sample to control for the effect of genetic interference on survivorship. Each egg mass was individually maintained in a white plastic container of $30 \times 20 \times 10 \mathrm{~cm}$ of size partially filled with water. Experiments with tadpoles began after hatching.

Glyphosate [Isopropylammonium N-(phosphonomethyl)glycinate] was purchased from Dow AgroSciences Industrial Ltda (Gliz 480 SL). Mineral water $(\mathrm{pH}=4.92)$ was used in the preparation of all solutions.

Acute toxicity tests were conducted using four replicates of five tadpoles, each kept in 1 liter of four selected concentrations of glyphosate solutions for 96 hours. The control consisted of tadpoles maintained only in mineral water. Concentrations of glyphosate were $0.8,1.6,3.2$ and $6.4 \mathrm{mg} \mathrm{L}^{-1}$. Feeding was not provided during the experiment. Observations were made on a daily basis and mortality was recorded. Mean temperature during this experiment was $31.2^{\circ} \mathrm{C}$. A Trimmed SpermanKarber (TSK) was used to determine the $\mathrm{CL}_{50}$ value and its confidence interval.

Survivorship rates of $P$. albonotatus were calculated for sub-lethal concentrations of glyphosate: 25,50 and $75 \%$ of $\mathrm{CL}_{50}$ values. Each replicate consisted of ten tadpoles kept in two liters plastic receptacles under experimental concentrations. Water was partially renewed every day. Tadpoles were fed ad libitum with fish meals. The mean temperature during this experiment was $31^{\circ} \mathrm{C}$. Dead individuals were enumerated three, five, seven, ten and eleven days after the beginning of the experiment. The last living tadpole died on the eleventh day. A survivorship graph was generated using an analysis of variance for repeated measures (ANOVA) performed in SYSTAT 12.

\section{RESULTS}

The 96-h $\mathrm{CL}_{50}$ of Glys $480 \mathrm{~S}$ for tadpoles of Physalaemus albonotatus from Cuiabá was $5.38 \mathrm{mg} \mathrm{L}^{-1}$.

The percentage of P. albonotatus tadpolemortality increased with an increase in glyphosate concentrations. Nevertheless, tadpoles maintained under sub-lethal concentrations of glyphosate were characterized by differential survivorship rates $(p=0.00004551)$ (Figure 1). There were statistical differences $(p<0.001)$ between different concentrations

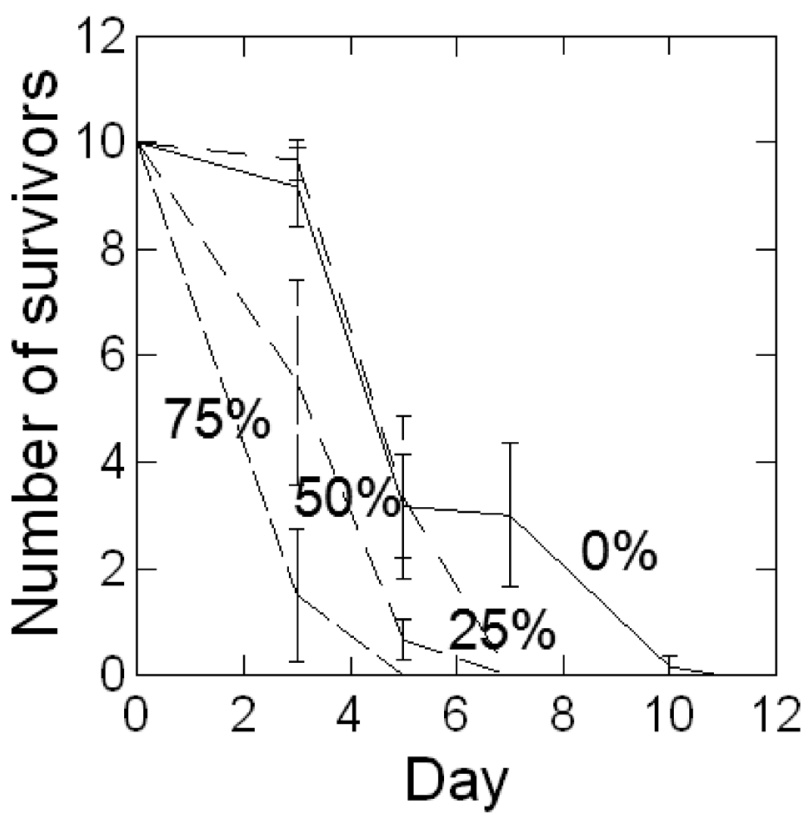

Figure 1 - The number of survivors of Physalaemus albonotatus tadpoles from Cuiabá, Mato Grosso, Brazil under control, 25, 50 and $75 \%$ of $\mathrm{CL}_{50}$ value of glyphosate by days of exposure in these concentrations. Overlap of vertical bars indicates no statistical difference and non-overlap bars shows statistical differences on survivorship. 
of glyphosate for tadpole survivorship and number of days survived. After four days there were no survivors in the $75 \%$ of $\mathrm{CL}_{50}$ treatment, and there was only one survivor after the second day. For $25 \%$ and $50 \%$ of $\mathrm{CL}_{50}$ treatments there were no tadpoles which survived longer than five days. After seven days, only tadpoles in the control (mineral water) treatment were still alive.

\section{DISCUSSION}

The $\mathrm{CL}_{50}$ value for Physalaemus albonotatus was four times smaller than the value found for a congeneric species (P. centralis, $\mathrm{CL}_{50} 19.7 \mathrm{mg} \mathrm{L}^{-1}$ ) using the same protocol (Figueiredo, 2010). Figueiredo (2010) found even higher values of $\mathrm{CL}_{50}$ for two other Brazilian amphibian species, the bufonid Rhinella marina $\left(\mathrm{CL}_{50}=32 \mathrm{mg} \mathrm{L}^{-1}\right)$ and the microhylid Elachistocleis sp. $\left(\mathrm{CL}_{50}=29.2 \mathrm{mg} \mathrm{L}{ }^{-1}\right)$. The discrepancy in values of $\mathrm{CL}_{50}$ for Brazilian anuran species may reflect a differential resistance of anurans species to herbicides. Indeed, Figueiredo (2010) collected egg masses in puddles 10-50 meters away from a soybean plantation in Northern Mato Grosso where glyphosate has been used for at least a decade. These puddles were temporary (present only during the rainy season from December to March) and used for spawning by several anuran species. Anuran species with different historical contact with pesticides may thus be developing tolerance and/ or may be in the midst of a population decline process.

The research protocols adopted for evaluating $\mathrm{CL}_{50}$ values of other anuran species differ somewhat from the present study making direct comparisons problematic. For example, Lajmanovich et al. (2003) tested Glys toxicity in tadpoles of Scinax nasicus (Hylidae) collected in Argentina, reporting a $\mathrm{CL}_{50}$ value of $3.62 \mathrm{mg} \mathrm{L}^{-1}$ (similar to that reported here). However, their experiment only lasted 48 hours rather than 96 hours. Mann \& Bidwell (1998) using the pesticide Roundup to determine the $\mathrm{CL}_{50}$ for four Australian anuran species belonging to three families: Hylidae (Litoria moorei), Myobatrachidae (Crinia insignifera, Heleioporus eyrei and Limnodynastidae (Limnodynastes dorsalis). This experiment lasted 48 hours and $\mathrm{CL}_{50}$ values ranged from 8.1 to $32.2 \mathrm{mg} \mathrm{L}^{-1}$. Also using roundup, Relyea (2005) determined the $\mathrm{CL}_{50}$ for six North American anuran species in three families: Ranidae (Rana sylvatica, $R$. pipiens, $R$. clamitans, $R$. catesbeiana), Bufonidae (Bufo americanus) and Hylidae (Hyla versicolor). This experiment lasted 16 days and values of $\mathrm{CL}_{50}$ ranged from 0.55 to $2.52 \mathrm{mg} \mathrm{L}^{-1}$. Relyea \& Jones (2009) also used a 96 hours protocol to determine the $\mathrm{CL}_{50}$ of Roundup in nine anuran species (three of them was not included in previous study). Rana pipiens, $R$. clamitans, $R$. sylvatica, $R$. catesbeiana, R. cascadae, Bufo americanus, B. boreas, Hyla versicolor, Pseudacris crucifer values of $\mathrm{CL}_{50}$ were $1.5,1.4$, $1.9,0.8,1.7,1.6,2.0,1.7$ and $0.8 \mathrm{mg} \mathrm{L}^{-1}$ respectively. Reyes et al. (2003) tested Glifosan for an Cuban anuran species (Osteopilus septentrionali, Hylidae) and the $\mathrm{CL}_{50}$ value in 96 hours was $20.81 \mathrm{mg} \mathrm{L}^{-1}$. Wojtaszek \& Staznik (2004) tested the pesticide Vision in Rana clamitans and R. pipiens using $a$
96 hours protocol, generating $\mathrm{CL}_{50}$ values of 2.70 and 11.50 $\mathrm{mg} \mathrm{L}^{-1}$ respectively.

Methodological differences in experiments (time of exposure, commercial formulae tested) make direct comparisons among studies difficult. Nevertheless, species specific tolerances of glyphosate are apparent. These differences may be due to phylogenetic factors (diverse families of anurans analyzed) as well as environmental conditions (differential exposure to glyphosate) and merit further investigation.

The positive relationship between mortality of tadpoles and increased glyphosate concentrations was anticipated. Cauble \& Wagner (2005) found the same pattern when they tested the effects of sub-lethal glyphosate concentrations (0ppm, $1 \mathrm{ppm}$ and $2 \mathrm{ppm}$ ) during 43 days in the metamorphosis and development of Rana cascadae (Ranidae). All tadpoles including the control died before they metamorphosed. At a concentration of $0.96 \mathrm{ppm}$ the authors recorded a mortality of $8.6 \%$, increasing to $51.4 \%$ when tadpoles were kept in a concentration of $1.94 \mathrm{ppm}$. Releya \& Jones (2009) obtained a similar pattern of increasing mortality with increasing pesticide concentration.

There was considerable variation in the response of Brazilian anuran species to sub-lethal concentrations of glyphosate. For example, Physalaemus centralis had higher mortality rates when kept in higher sub-lethal concentrations of glyphosate $\left(25,50\right.$ and $75 \%$ da $\left.\mathrm{CL}_{50}\right)$. For Rhinella marina, $50 \%$ and $75 \%$ of $\mathrm{CL}_{50}$ also affected survivorship, although for Elachistocleis $s p$. differences in mortality among different sub-lethal concentrations were not statistically significant (Figueiredo, 2010).

In conclusion, glyphosate exposure poses a different level of threat to different anuran species. However, further research is needed to assess whether resistance is influenced by phylogenetic signature, tolerance and/or historical contact with pesticides. Standardized protocols and additional studies on Brazilian anuran species are necessary to gain a better understanding of the impact of pesticides on Brazilian amphibians.

\section{ACKNOWLEDGMENTS}

We thank Fundação Oswaldo Cruz (FIOCRUZ), Conselho Nacional de Desenvolvimento Científico e Tecnológico (CNPq/CT-SAÚDE number 18/2006) for financial support. We thank ICMBio/SISBio for collecting permits (number 25209-1) and Ethical commitee for animal research (number 23108.044717/10-4) for experimental permits. Thanks to R.J. Ladle for proof-reading the manuscript.

\section{REFERENCES}

BARJA, B. C. \& SANTOS, M. A., 2005, Aminomethylphosphonic acid and glyphosate adsorption onto goethite: a comparative study. Environ. Sci. Technol., 39: 585-592. http://dx.doi. org/10.1021/es035055q 
BEEBEE, T. J. C. \& GRIFFITHS, R. A., 2005, The amphibian decline crisis: A watershed for conservation biology? Conserv. Biol., 125: 271-285. http://dx.doi.org/10.1016/j.biocon.2005.04.009

BERRILL, M., BETRAM, S., MCGILLIVRAY, L., KOLOHAN, M. \& PAULI, B., 1994, Effects of low concentrations of forestuse pesticides on frog embryos and tadpoles. Environ. Toxicol. Chem., 13: 657-664. http://dx.doi.org/10.1002/etc.5620130416

CAUBLE, K. \& WAGNER, R. S., 2005, Sublethal effects of herbicide glyphosate on amphibian metamorphosis and development. Bull. Environ. Contam. Toxicol., 75: 429-435. http://dx.doi. org/10.1007/s00128-005-0771-3

DAVIDSON, C., SHAFFER, H. B. \& JENNINGS, M. R., 2001, Declines of the California red-legged frog: Climate, UV-B, habitat, and pesticides hypotheses. Ecol. Appl., 11: 464-479. http://dx.doi. org/10.1890/1051-0761(2001)011[0464:DOTCRL]2.0.CO;2

DAVIDSON, C., SHAFFER, H. B. \& JENNINGS, M. R., 2002, Spatial tests of the pesticide drift, habitat destruction, UV-B and climate change hypotheses for California amphibian declines. Conserv. Biol., 16: 1588-1601. http://dx.doi.org/10.1046/j.15231739.2002.01030.x

DAVIDSON, C., 2004, Declining downwind: Amphibian population declines in California and historical pesticide use. Ecol. Appl., 14: 1892-1902. http://dx.doi.org/10.1890/03-5224

FOLMAR, L. C., SANDERS, H. O. \& JULIN, A. M., 1979, Toxicity of the herbicide glyphosate and several of its formulations to fish and aquatic invertebrates. Arch. Environ. Con. Tox., 8: 269-278. http://dx.doi.org/10.1007/BF01056243

FROST, Darrel R., 2011, Amphibian Species of the World: an Online Reference. http://research.amnh.org/vz/herpetology/amphibia/ American Museum of Natural History. Accessed 27 June 2011.

FULTON, M. H. \& CHAMBERS, J. E., 1985, The toxic and teratogenic effects of selected organophosphorus compounds on the embryos of three species of amphibians. Toxicol. Lett., 26: 175-180. http://dx.doi.org/10.1016/0378-4274(85)90163-8

HADDAD, C. F. B. \& PRADO, C. P. A., 2005, Reproductive Modes in Frogs and Their Unexpected Diversity in the Atlantic Forest of Brazil. Bioscience, 55: 207-217. http://dx.doi.org/10.1641/00063568(2005)055[0207:RMIFAT]2.0.CO;2

HAYES, T. B., CASE, P., CHUI, S., CHUNG, D., HAEFFELE, C.; HASTON, K. L. M., MAI, V. P., MARJUOA, Y., PARKER, J. \& TSUI, M., 2006, Pesticide mixtures, endocrine disruption, and amphibian declines: Are we underestimating the impact? Environ. Health Persp., 114: 40-50. http://dx.doi.org/10.1289/ ehp. 8051

HAYES, T. B., FALSO, P., GALLIPEAU, S. \& STICE, M., 2010, The cause of global amphibian declines: a developmental endocrinologist's perspective. J. Exp. Biol., 213: 921-933. http:// dx.doi.org/10.1242/jeb.040865

HOULAHAN, J. E, FRIDLAY, C. S., SCHMIDT, B. R., MAYERS, A. H. \& KUZMIN, S. L., 2001, Quantitative evidence for global amphibian population declines. Nature, 404: 752-755. http:// dx.doi.org/10.1038/35008052

JUNIOR, O.P.A.\& SANTOS, T.C.R., 2002, Glifosato: propriedades, toxicidade, usos e legislação. Quim. Nova, 25: 589-593.

LAJMANOVICH, R. C, SANDOVAL, M. T. \& PELTZER, P. M., 2003, Induction of mortality and malformation in Scinax nasicus tadpoles exposed to glyphosate formulations. Bull. Environ. Contam. Toxicol., 70: 612-618. http://dx.doi.org/10.1007/ s00128-003-0029-x

LANGIANO, V. C. \& MARTINEZ, C. B. R., 2008, Toxicity and effects of a glyphosate-based herbicide on the Neotropical fish Prochilodus lineatus. Comp. Biochem. Phys. C., 147: 222-231. http://dx.doi.org/10.1016/j.cbpc.2007.09.009
LAWRENCE, E. \& ISIOMA, T., 2010, Acute toxic effects of Endosulfan and Diazinon pesticides on adult amphibians (Bufo regularis). J. Environ. Chem. Ecotoxicol., 2: 73-78.

MANN, R. M. \& BIDWELL, J. R., 1999, The toxicity of glyphosate and several glyphosate formulations to four species of Southwestern Australian Frogs. Arch. Environ. Con. Tox., 36: 193-199. http://dx.doi.org/10.1007/s002449900460

MAY, R. M., 2010, Ecological science and tomorrow's world. Philos. T. Roy. Soc. B., 365: 41-47. http://dx.doi.org/10.1098/ rstb.2009.0164

PACHECO, P., 2009, Brasil lidera uso mundial de agrotóxicos. Economia e negócios. http://estadao.com.br/ estadaohoje/20090807/notimp414820,0.php. Accessed 09 June 2011.

RELYEA, R. A., 2005, The lethal impact of Roundup on aquatic and terrestrial amphibians. Ecol. App., 15: 1118-1124. http://dx.doi. org/10.1890/04-1291

RELYEA, R. A. \& JONES, D. K., 2009, The toxicity of Roundup Original MAX ${ }^{\mathrm{TM}}$ to 13 species of larval amphibians. Environ. Toxicol. Chem., 28: 2004-2008. http://dx.doi.org/10.1897/09021.1

REYES, M.E.A., HONDAL, O.C.HERNANDEZ, J. T. \& ALEMAN, M. A. T., 2003, Toxicidad aguda del Herbicida químico Glifosan en larvas de la rana cubana: Osteopilus septentrionalis. Revista de Toxicologia en Linea, 34-45.

ROMANO, R. M., ROMANO, M. A., MOURA, M. O.\& OLIVEIRA, C. A., 2008, A exposição ao glifosato-Roundup causa atraso no início da puberdade em ratos machos. Braz. J. Vet. Res. An. Sci., 45: 481-487.

SCHIESARI, L. \& GRILLITSCH, B., 2011, Pesticides meet megadiversity in the expansion of biofuel crops. Front. Ecol. Environ., 9: 215-221. http://dx.doi.org/10.1890/090139

SPARLING, D. W., LINDER, G. \& BISHOP, C. A., 2000, Ecotoxicology of amphibians and reptiles. Pensacola, FL, SETAC - Society of Environment Toxicology and Chemistry, $877 \mathrm{p}$.

STUART, S. N., CHANSON, J. S., COX, N. A., YOUNG, B. E., RODRIGUES, A. S. L., FISCHMAN, D. L. \& WALLER, R. W., 2004, Status and trends of amphibian declines and extinctions worldwide. Science, 306: 1783-1786. http://dx.doi.org/10.1126/ science. 1103538

TSK, Trimmed Spearman-Karber program version 1.5. Ecological Monitoring Research Division. EPA - U.S. Environmental Protection Agency, Cincinati, Ohio. Available in: http://www. epa.gov/nerleerd/stat2.htm. Acessed 10 June 2011.

VEREECKEN, H., 2005, Mobility and leaching of glyphosate: a review. Pest Manag. Sci., 61: 1139-1151. http://dx.doi. org/10.1002/ps.1122

WAKE, D. B. \& VREDENBURG, V. T., 2008, Are we in midst of the sixth mass extinction? A view from the world of amphibians. P. Natl. Acad. Sci. USA, 105: 11466-11473. http://dx.doi. org/10.1073/pnas.0801921105

WILKINSON, L., 2007. SYSTAT: The System for Statistics. SYSTAT, Inc., Evanston, Illinois, USA.

WOODBURN, A. T., 2000, Glyphosate: production, pricing, and use worldwide. Pest Manag. Sci., 56: 309-312. http:// dx.doi.org/10.1002/(SICI)1526-4998(200004)56:4<309::AIDPS143>3.0.CO;2-C

WOJTASZEK, B. F. \& STAZNIK, B., 2004, Effects of Vision herbicide on mortality, avoidance response, and growth of amphibian larvae in two forest wetlands. Environ. Toxicol. Chem., 23: 832-842. http://dx.doi.org/10.1897/02-281. 